\title{
Improving Information Flow for Decision Making on Product Quality in the Automotive Industry
}

DOI: 10.12776/QIP.V22I1.1082

\author{
Andrea Sütöová, Simona Segiňáková
}

Received: 07 February 2018 Accepted: 16 March 2018 Published: 31 March 2018

\begin{abstract}
Purpose: The purpose of the paper is to identify improvement possibilities in the data processing and information flow relating to product quality in the processes of automotive component production, which might result in the acceleration of decision making on product quality and reduction of defects and related costs. The expected results of the proposed improvement are presented in the paper.
\end{abstract}

Methodology/Approach: Modelling and simulations of the component production processes with the current and proposed state of information flow were made in the QPR software to test the effect of the changes in the information flows. Subsequently, the results of the simulations of both process models were compared from the perspective of quality.

Findings: Results of the simulations showed the positive effect of the proposed changes reflecting in the lower number of defects compared to the current state. Based on the accurate and timely received information on product quality, needed interventions to the process can be realized to reduce the defects.

Research Limitation/implication: The limitation of the paper is the exact estimation of benefits after the improvement implementation. The expected benefits were defined on the base of test operation.

Originality/Value of paper: The originality of the paper is in the applicability of the proposed solution in organisations operating in the automotive industry or other data-driven manufacturing organisations calling for timely and accurate information access to achieve a high level of quality, effectiveness and efficiency in the production processes.

Category: Research paper

Keywords: information; information flow; product quality; decision making; process modelling 


\section{INTRODUCTION}

Decisions in organizations are made at all hierarchical levels. Factual approach to decision making plays an important role in quality management in organisations. Fact-based decision making according to (ISO, 2015) considerably emphasises data and information analysis as a basis for decision making rather than just subjective opinion (Nenadál, et al., 2008). The need of facts for objective decision making is also highlighted by the words of Edward Deming: "Without data you're just another person with an opinion" (Anderson, 2015).

Effective data collection is a first step in the implementation of the factual approach to decision making. Data must be accessible, accurate and reliable and transferred on the base of a query by using appropriate tools to needed information (Anderson, 2015). Information is a meaningful data or interpretation of data (Wang, 2015). The information comes from selecting data, summarising it and presenting it in such a way that it is useful to the recipient (Hinton, 2011). Optimally designed information flow makes information accessible to those who need it. Information flow in organisation is timely, relevant and appropriate flow of information from a sender (transmitter) at point $\mathrm{A}$ to a receiver (recipient) at point B (Durugbo, Tiwari and Alcock, 2013). Information flow is a lifeblood of the organisation ensuring the needed information is available for relevant organisation processes, activities and people. According to (Durugbo, Tiwari and Alcock, 2010) information flow is determined by main three dimensions: information access, information exchange and documentation (Berente, Vandenbosch and Aubert, 2009). The focus of the paper is on the information access in order to support decision making, which relates to the presence of the information and the ease with which the information can be retrieved.

There are various Management support systems used in organisations to ensure the needed information are delivered to all managers (from strategic to operational level) for effective execution of management functions. Management support systems can be divided according to their use in organization's management levels as follows (Anderson, 2015): Executive Information Systems (EIS) - serves for top management; Decision Support Systems (DSS) - serves for middle-level management and Management information systems (MIS) serves for low-level and middle-level management. Mostly the term Management Information System (MIS) is used in the literature as an umbrella of the abovementioned support systems. The MISs convert data into information and communicate that information in an appropriate form to managers at all levels to make timely and effective decisions (Lucey, 2005).

Organizations operating in automotive industry generate a huge amount of manufacturing data. Management approaches emphasise data-driven decision making in the automotive industry more than in many other industries. Datadrivenness is about building tools, abilities, and culture that acts on data (Zgodavová, Hudec and Palfy, 2017). It requires robust solutions with efficient data collection, business intelligence capabilities and analysis support speeding 
up reactions upon time-sensitive data coming off the shop floor (Lengyel, 2013). The MISs help managers to get in touch with every activity running in a workplace and can help make valid decision by providing accurate and up-todate information and performing an analytical function. Timely provided information is crucial for effective quality assurance. If the needed information is provided quickly enough, the problem can be recognised and suitable corrective actions can be implemented to avoid the problem reoccurrence (Nagyová and Palko, 2016). Corrective action requires understanding of quality problems. Therefore there is a need to ensure effective information flow and to make necessary information timely accessible to those who need them in the process of decision making related to quality improvement activities.

Information needs of managers are the basis for projection and improvement of Management information systems. It is necessary to ensure the effectiveness of MIS, which enable to select and provide the needed information on time and transmit it to those who need it. It is a challenge for organisations to better understand and manage processes for capturing, utilisation of data and improve information flow in the organisation to support decision making (Laudon and Laudon, 2013). In order to find ways how to improve the information flow, it is crucial to understand.

- Who needs the information?

- What information is needed?

- Where is the information stored?

- When to use the information?

- How does the information support the particular process?

Information flow is an important part of workflows (Al-Halkim, 2008). Process modelling enables to graphically present the process steps and activities within the process (Zgodavová and Lengyel, 2011). It also It can serve as a means for understanding of the present state and identifying potential improvements in workflow and dataflow (Sadiq, et al., 2004). Process modelling is usually used to map two different states of the process: As-is, the state of the process as it is right now, without making any changes or improvements, and To-be, the future state, after making changes or improvements.

The research presented in the paper uses the process modelling for describing of the automotive component production processes and information flow within these processes before and after the proposed changes in the information flows. The simulation of the process models (present and future state) enabled to show the expected effect of the changes in the information flows on the product quality. 


\section{METHODOLOGY}

The research was conducted in the supplier organisation producing interior components for automotive industry such as dashboards, door panels, armrests and centre consoles. The organisation has recently implemented the new Information System (IS), which is used for data acquisition in the production processes and its immediate evaluation and smart online reporting according to user`s requirements. The IS enables paperless data acquisition at workplace via industrial touch screens, tablets or automatic connection to the selected devices. Before the implementation of the IS, data were recorded on the paper checklists, dispatch notes and entered then to the system. The implementation of the IS brought significant improvement in data acquisition and information sharing. Quality data are actual and correctly recorded in the place and time of their generation and processed immediately and systematically. It helps competent employees to gain access to the needed information for right decision making in the production processes. This solution significantly reduced operators' working time and accelerated analytical activities and decision making.

The system can be further improved and tailored, and new possibilities of data and information utilisation are seeking in the organisation to improve quality, productivity and reduce production costs. After getting acquainted with the production processes and current information flows in the organization, improvements in data processing and information flows were proposed which might result in the acceleration of decision making related to product quality and reduction of defects and related production costs.

Fig. 1 shows the process of the door panel production consisting of the leather and PVC processing and glue preparation for the wood fibre coating and processing. It also shows the data flow from the quality control processes in the central database to be processed. There are also visible the proposed information flows in the production processes if there are at least three identical defects. The current conditions enable to get valuable information on product quality in the form of various reports to all competent employees according to their needs. However, the information system is unable to send an automatic warning notification about increasing number of identical defects to those who make a decision in production processes. The proposed change in data processing and information flow will enable to send an automatic warning notification in the case of at least three identical defects, which will be displayed via touch screens in every workplace, where the defect could be generated. Thus the information will get to the production in real time to right workplaces and all competent employees. The decision and improvements in the production processes will be made on time, which will have a positive effect on product quality and production costs. After the notification-receiving, it will have to be confirmed by the competent employee and corrective actions will be implemented on the base of the information. Counting of the identical defects will start again after the confirmation of the last notification. 


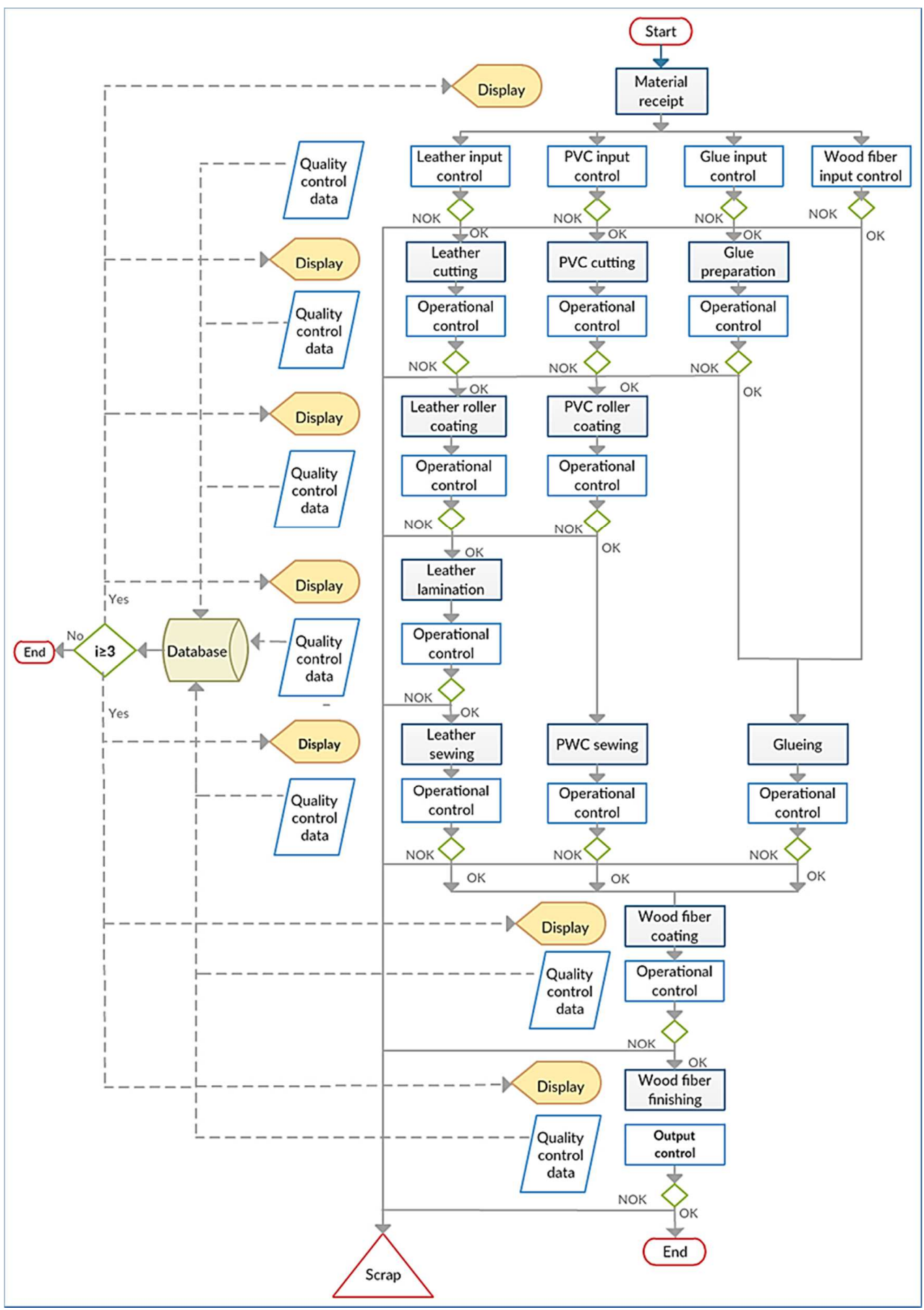

Figure 1 - Flowchart of the Component Production Process

To test the effect of the proposed changes, the simulations were made in the QPR Process Guide 8.1 software. The simulations of the current process model and 
process model with the improved information flow were realised to compare the result. In order to run the simulation, real process parameters were entered to the QPR software, which were time duration of the individual activities, resources assigned to the activities and probability of the defect occurrence in the case of decision blocks. The probability of defect generation was entered to the system based on the information gained from the central IS of the organisation to simulate the current process model. For the simulation of the proposed model with the changes in information flow, the probability of the defects occurrence were reduced based on the results of the test operation and implementation of corrective action after receiving the notification in particular processes. For both of the models, five simulations were run.

\section{RESULTS AND CONCLUSION}

Tab. 1 shows the results of the process models simulations. The results indicate the lower number of defects in the case of the proposed process model in comparing to the current one. The total sum of the difference is 75 defects, which means a reduction of defects by $54 \%$. The higher difference in defects generation is in the process of Wood fibre coating.

Table 1 - Results of Simulation of the Current and Proposed Process Model (Source: Segiňáková, 2017)

\begin{tabular}{|l|c|c|c|}
\hline $\begin{array}{c}\text { Operational control in } \\
\text { the processes }\end{array}$ & $\begin{array}{c}\text { Average number } \\
\text { of defects (current } \\
\text { state) }\end{array}$ & $\begin{array}{c}\text { Average number } \\
\text { of defects } \\
\text { (simulated state) }\end{array}$ & $\begin{array}{c}\text { Difference in the } \\
\text { number of defects }\end{array}$ \\
\hline PVC cutting & 2 & 2 & 0 \\
\hline Leather cutting & 27 & 21 & 6 \\
\hline Gluing & 29 & 22 & 7 \\
\hline Leather lamination & 2 & 1 & 1 \\
\hline Sewing & 3 & 2 & 59 \\
\hline Wood fibre coating & 74 & 15 & 75 \\
\hline$\sum$ & 138 & 63 & 1 \\
\hline
\end{tabular}

Accurate, timely and useful information are necessary for effective decision making in the production processes and implementation of improvements. Data generated in the production processes should be processed in a way enabling to provide useful information and transmitted it in the right time to right people. The automatic information providing an increasing number of identical defects within the production processes in real time enables to identify problem's causes and implement corrective actions on time what significantly improve quality of production and reduce costs related to defected products. 


\section{ACKNOWLEDGEMENTS}

This paper was developed within the project KEGA 024TUKE-4/2015 "New educational methods in the integrated management study programme", supported by the Slovak Ministry of Education and Sport.

\section{REFERENCES}

Al-Halkim, L., 2008. Modelling information flow for surgery management process. International Journal of Information Quality, [e-journal] 2(1), pp.60-74. http://dx.doi.org/10.1504/IJIQ.2008.019563.

Anderson, C., 2015. Creating a Data-Driven Organization. Sebastopol: O'Reilly Media.

Berente, N., Vandenbosch, B. and Aubert, B., 2009. Information flows and business process integration. Business Process Management Journal, [e-journal] 15(1), pp.119-141. http://dx.doi.org/10.1108/14637150910931505.

Burstein, M. and Diller, D., 2004. A framework for dynamic information flow in mixed-initiative human/agent organizations. Applied Intelligence, 20(3), pp.283289.

Durugbo, C., Tiwari, A. and Alcock, J., 2010. Managing Information Flows for Product-Service Systems Delivery. Linkoping: Linkoping University.

Durugbo, C., Tiwari, A. and Alcock, J., 2013. Modelling information flow for organizations: A review of approaches and future challenges. International Journal for Information Management, [e-journal] 33, pp.597-610. https://doi.org/10.1016/j.ijinfomgt.2013.01.009.

Hinton, M., 2011. Introducing Information Management: The Business Approach. New York: Routledge.

ISO, 2015. ISO 9000:2015 Quality management systems: Fundamentals and vocabulary. Geneva: ISO.

Laudon, K. and Laudon, J., 2013. Management Information Systems: Managing the digital firm. London: Pearson Education Limited.

Lengyel, L., 2013. Production data acquisition and analysis management system: An example based on a study of automotive supplier solution. Quality Innovation Prosperity, [e-journal] 17(2), pp.103-110. http://dx.doi.org/10.12776/qip.v17i2.260.

Lucey, T., 2005. Management information systems, London: Thomson Learning.

Nagyová, A. and Palko, M., 2016. Analysis of the causes of nonconforming product in supplier-customer chain. In: M. Majerník, N. Daneshjo and M. Bosák, ed. 2016. Production Management and Engineering Sciences. London: Taylor \& Francis. pp.213-218. 
Nenadál, J., Noskievičová, D., Petř́íková, R., Plura, J. and Tošenovský, J., 2008. Moderní management jakosti: principy, postupy, metody. Praha: Management Press.

Sadiq, S., Orlowska, M., Sadiq, W. and Foulger, C., 2004. Data flow and validation in workflow modelling. Darlinghurst: ADC.

Segiňáková, S., 2017. Zlepšenie toku informácií pre rozhodovanie o kvalite produktov v organizácii automobilového priemyslu. Kosice: Technická univerzita $\mathrm{v}$ Košiciach.

Wang, Y., 2015. Formal Cognitive Models of Data, Information, Knowledge and Intelligence. WSEAS Transactions on Computers, 14(3), pp.770-781.

Zgodavová, K. and Lengyel, L., 2011. Modeling and Simulating Relocation of a Production in SIMPRO-Q Web Based Educational Environment. In: IEEE, 14th International Conference on Interactive Collaborative Learning (ICL). Piešt'any, Slovakia, $\quad 1-23 \quad$ September $2011 . \quad$ IEEE. https://doi.org/10.1109/ICL.2011.6059638.

Zgodavová, K., Hudec, O. and Palfy, P., 2017. Culture of quality: insight into foreign organisations in Slovakia. Total Quality Management and Business Excellence, [e-journal] 28(8-9), pp.1-22. https://doi.org/10.1080/14783363.2017.1309120.

\section{ABOUT AUTHORS}

Andrea Sütőová, Ing., PhD. is a lecturer at the Department of Materials and Quality Engineering of the Faculty of Materials, Metallurgy and Recycling of the Technical University of Kosice, Slovakia. Her professional activities are focused on the field of Quality management systems, Process management and improvement, Open innovation and Human resource management. She has been a member of various national and international projects oriented mainly to Quality management, Metrology, Process improvemnet and Open innovation, e-mail: andrea.sutoova@tuke.sk.

Simona Segiňáková, Ing., graduated from the Technical University of Kosice and earned her master's degree in the field of Quality of Production. Currently, she is working in T-systems company.

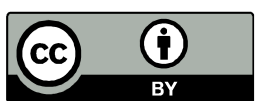

(C) 2018 by the authors. Submitted for possible open access publication under the terms and conditions of the Creative Commons Attribution (CC-BY) license (http://creativecommons.org/licenses/by/4.0/). 